TIGG Vol.2 No.8 (1990)

MINIREVIEN (TIGG-11/02/90-MR-2)

\title{
Gangliosides as Modulators of Synaptic Transmission and Long-Term Neurconal Adaptation
}

\author{
Hinrich RAHMANN
}

Institute of Zoology, University of Stuttgart-Hohenheim, D-7000 Stuttgart 70 (Hohenheim), Fed. Rep. Germany, FAX: 49-711-459-3450

\section{INIRODUCTION}

Gangliosides $1=$ amphiphilic sialic acid-containing glycosphingolipids) are components of all plasma membranes and as such ubiquitous in vertebrate tissues. They are especially abundant and complex in neuronal membranes, where they are anchored in the outer leaflet of the membrane bilayer by their hydrophobic ceramide moiety, while exposing their negatively charged hydrophilic and spacious sialooligosaccharide chain into the extracellular space (Fig. 1). More than 100 different ganglioside species have been identified since Ernst Klenk discovered them in 1935 (for review comp. 1), differing with respect to the chain length, sequence and the number and linkage of sialic acids to the sugar residues. Together with neutral glycolipids, glycoproteins and glycosaminoglycans, gangliosides comprise the glycocalix of the cell surface of deuterostomian animals $(=$ echinoderms and chordates, including the vertebrates, 2). In contrast in Protostomia ( = lower invertebrates, like worms, arthropods, molluscs etc.), animals which are devoid of sialic acids, it appears as though sialic acids may be replaced by other sugars, e.g. by glucuronic acid (mussels, flies) or aminophosphonic acid (snails, 3).

Over the past few years, several thousands of articles on gangliosides have been published demonstrating their structure, physical and chemical properties, occurrence in the animal kingdom, organ and cellular distribu- tion and metabolism (for review comp. 4-7). The possible functional role of these "sphinx-like" glycosphingolipids in biological processes, however, remains still obscure. The results of research on gangliosides obtained so far have shed light not only on possible functional roles of these lipids with regard to participation in cell recognition, cell-to-cell contact formation, receptor binding and modulation, immunological phenomena, biosignal transduction etc., but have also unexpectedly opened up a whole new field of possible therapeutic applications of gangliosides in case of various neurophathies of different etiology $(8,9)$. With regard to this, recently significant correlations especially between cell growth, cellular differentiation, oncogenic transformation and tumor progression on the one side, and profound changes in ganglioside composition and biosynthesis, on the other side, have been demonstrated (for review comp. 10-12).

Concerning neuronal cell systems exogenously applied gangliosides were found to stimulate rather than inhibit cell growth, and to have neuritogenic and neuronotrophic properties, capable of influencing not only proliferation and differentiation of nerve cells in vitro, but also neuronal maintenance, survival, and repair in vivo (13). However, since some of the latter studies are still partly contradictory (14), this aspect will not be discussed here, as this special field of research is growing rapidly and has been 
シナブス伝達と長期神軽通压の䚴竽因子としてのガンクリオシド

\author{
Hinrich RAHMANN
}

\section{1. 序章}

ガングリオシドすなわち両親媒性のシアル 酸含有スフィンゴ糖脂質は、すべての細胞質 膜の構成要素であり、そのようにして脊椎動 物の組織に偏在する。それは二重膜構造の外 側の膜にその㻋水性のセラミドにより挿入さ れ、陰性の電荷を持つ親水性の大きなシアロ オリゴ糖鎖を細胞の外側に露出しており、特 に神経系の膜に多量に存在し、しかも複雑な 構造をとっている(Fig.1)。ガングリオシドの 種類は糖鎖の長さや配列、そしてシアル酸の 数や糖鎖への結合様式の違いによって区別さ れるが、1935年にErnst Klenkが発見して以来 100を超えるガングリオシドが同定されている。 中性の糖脂質、糖蛋白質やグリコサミノグリ カンとともにガングリオシドは第 2 胚門の動 物 ( = 棘皮動物門と脊索動物、脊椎動物を含 む）の細胞膜の複合糖質を構成している(2)。 これに対して原口動物（=ミミズのような虫、 節足動物、軟体動物などの下等な無脊椎動物） は、シアル酸を持たないが、シアル酸はグル
クロン酸（ムラサキガイ、ハエ）やアミノホ スフォン酸（ナメクジ、3）のようなほかの榶 で置き換えられているようである。

過去数年間に数千のガングリオシドに関す る文献が、その構造、物理的化学的性質、動 物界における発現、組織と細胞における分布 や代謝について述べている（総説は4-7参照）。 しかしながら、生物学的な過程におけるこれ ら“スフィンクスのように謎めいた”スフィ ンゴ糖脂質の機能的役割はまだはっきりして いない。これまでに得られたガングリオシド に関する研究の結果は、細胞認識や細胞間の 結合、受容体への結合やその調節、免疫学的 現象、生物情報伝達などへの関与といったこ れら脂質の機能的役割の可能性に光を当てた ばかりでなく、意外にも、異なった病因による 種々の神経病の症例においてガングリオシド が治療目的に使用できうるというまったく新 しい分野を開拓した $(8,9)$ 。このことに関して は、最近特に細胞增殖、細胞分化、虞化や腫 演の增殖といった現象と、ガングリオシドの
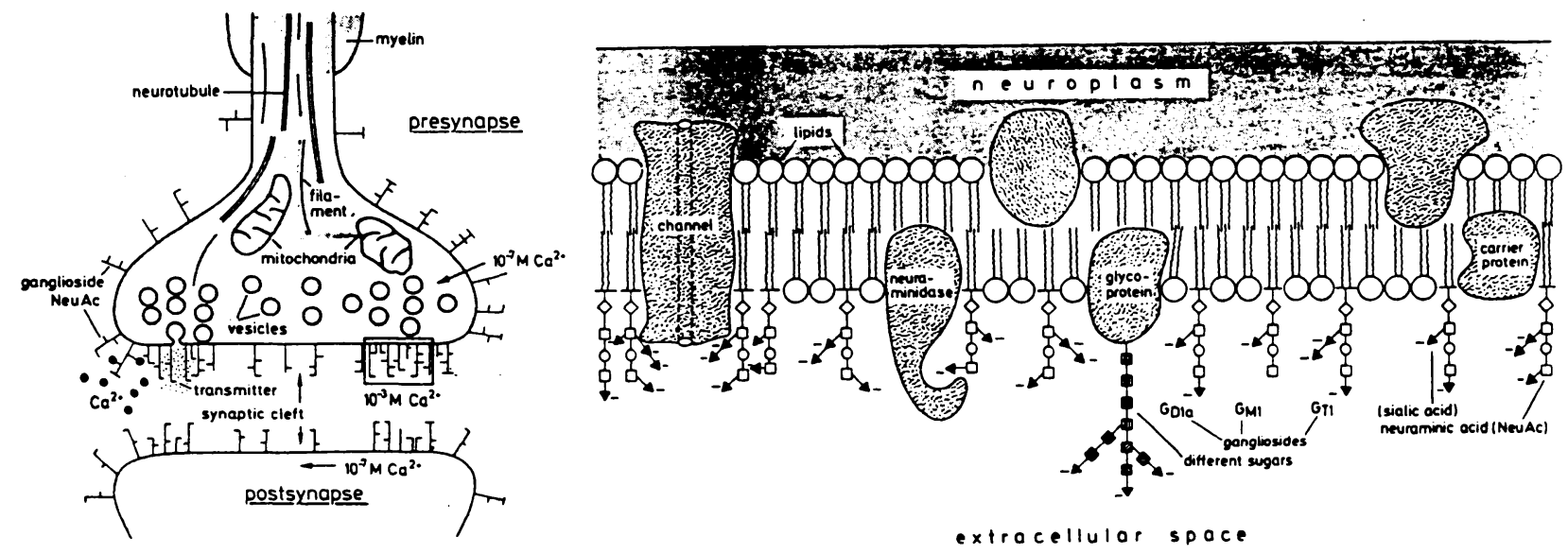

Fig. 1. Scheme of symaptic terminal with ganglioside cluster in the outer membrane surface; enlargement: molecular scheme of the membrane including the arrangement of differently polar gangliosides, integral proteins, carrier- and channel proteins and the enzyme neuraminidase, cleaving sialic acids. 
TIGG Vol. 2 No.8 (1990)

MINIREVIEN (TIGG-11/02/90-MR-2)

reviewed several times $(8,9,14)$. Our knowledge of the possible functional role of endogenous gangliosides in the cellular metabolism, up to now, is still unsatisfactory.

Focussing particularly on the nervous system the present article will try to summarize the current knowledge regarding the possible functional role of gangliosides in neuronal events. With regard to this it has to be emphasized that almost every stage of neuronal activity, especially electroresponsiveness, can be modified significantly by changes in the extracellular calcium concentration. While intracellular $\mathrm{Ca}^{2+}$ ( $\mu \mathrm{M}$ concentration) within the synaptic terminal was found to act as a secondary messenger for triggering the metabolic reactions of the cell, extracellular $\mathrm{Ca}^{2+}$ (mM concentration) is assumed to function as a primary messenger, enabling the internalization of external signals, which in case of neurons means the internalization of the electrically coded information from the pre- to the postsynaptic terminal. It is supposed that changes in the physico-chemical properties of the synaptic membranes are responsible for the short-term event of synaptic transmission of informations as for longterm adaptation processes (e.g. thermal adaptation, regeneration, information storage, 15-20).

On this background the present review will refer to a survey of some major physiological, bio-electrical, biochemical and physicochemical peculiarities of brain gangliosides. In addition a working hypothesis on the possible involvement of brain gangliosides as modulators of synaptic transmission and long-term neuronal adaptive processes will be discussed (comp. 1520).

2. Synopsis of physiological, bio- electrical, biochemical and physico-chemical peculiarities of brain gangliosides

Since the number of publication in the various fields of scientific activities of ganglioside research is to some extend overwhelmingly large, in this presentation the discussion of results is focused mainly on those topics which are of special significance for the interpretation of the possible functional role of gangliosides in synaptic transmission and storage of information within the nervous system.

2.1. Physiological peculiarities of brain gangliosides

For an understanding of the physiological functions of gangliosides in nerve cells it may prove important to have detailed knowledge about the occurrence of these glycosphingolipids among the animal kingdom as well as the ontogenetic development including genetic mutants.

2.1.1. Phylogenetic and ecophysiological aspects (for review comp. $2,6,18,21-23)$

The brain gangliosides vary significantly in concentration and composition (e.g. degree of sialylation = polarity), depending on the phylogenetic level of nervous organization and the ecophysiological adaptation of the vertebrates to their temperature environment. In lower ectothermic, coldblooded vertebrates (fish, amphibians, reptiles) the content varies between 100 and $800 \mu \mathrm{g}$ sialic acid/g fresh wt. of brain; in endothermic, warm-blooded birds and mammals it ranges between 400 and $1500 \mathrm{\mu g}$. (Concomitantly a significant decrease in the content of neuronal sialo-glycoproteins is observed). Comparing the ganglioside content from single brain structures (e.g. forebrain, midbrain, brain stem, cerebellum, spinal cord), a general 


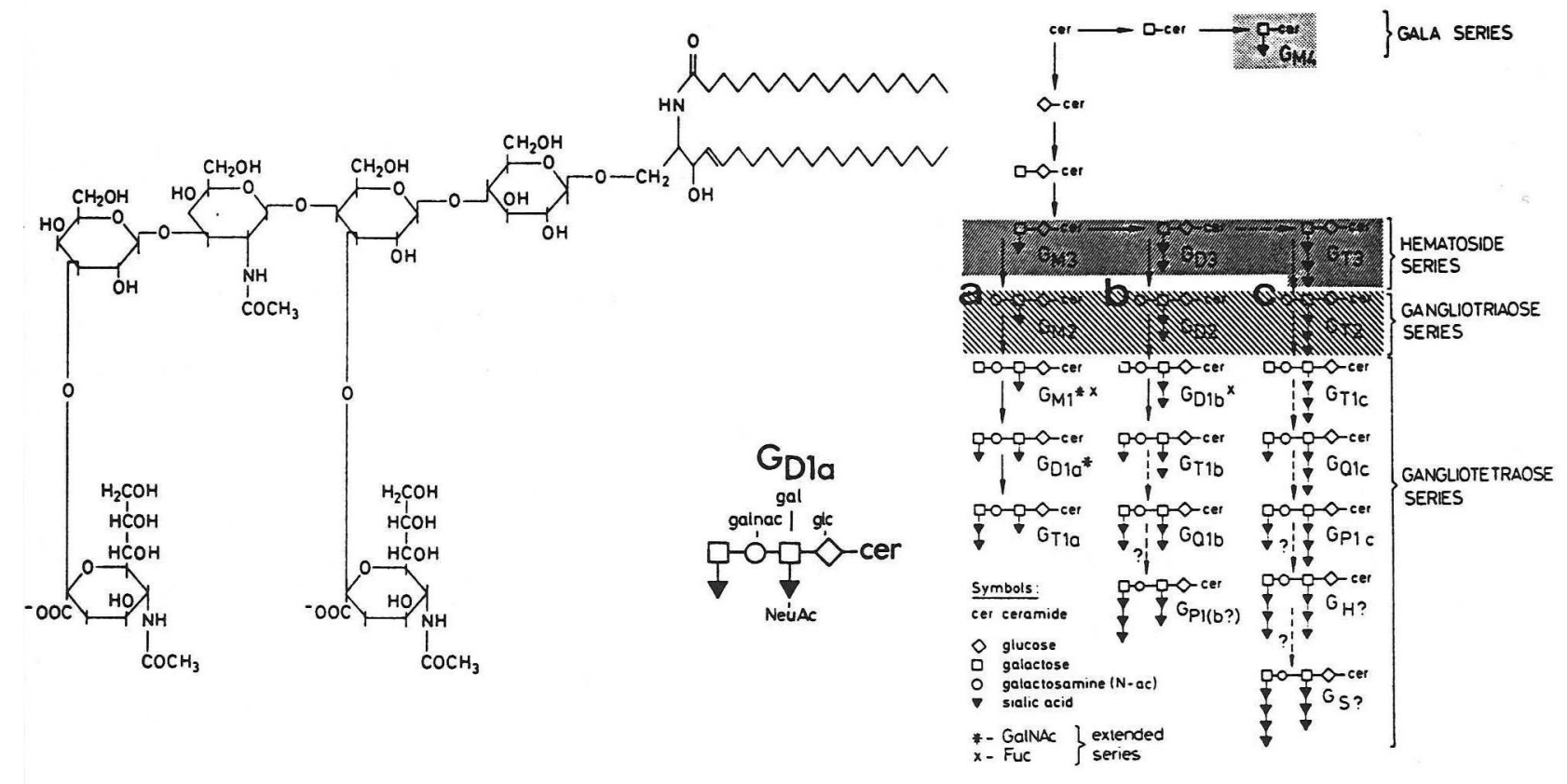

Fig. 2. Molecular structure of the di-sialogangliosides $\mathrm{GD}_{1 \mathrm{a}}$ and major pathways $(a, b, c)$ of ganglioside biosynthesis.

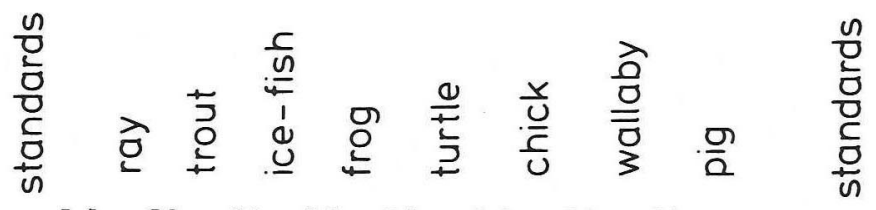

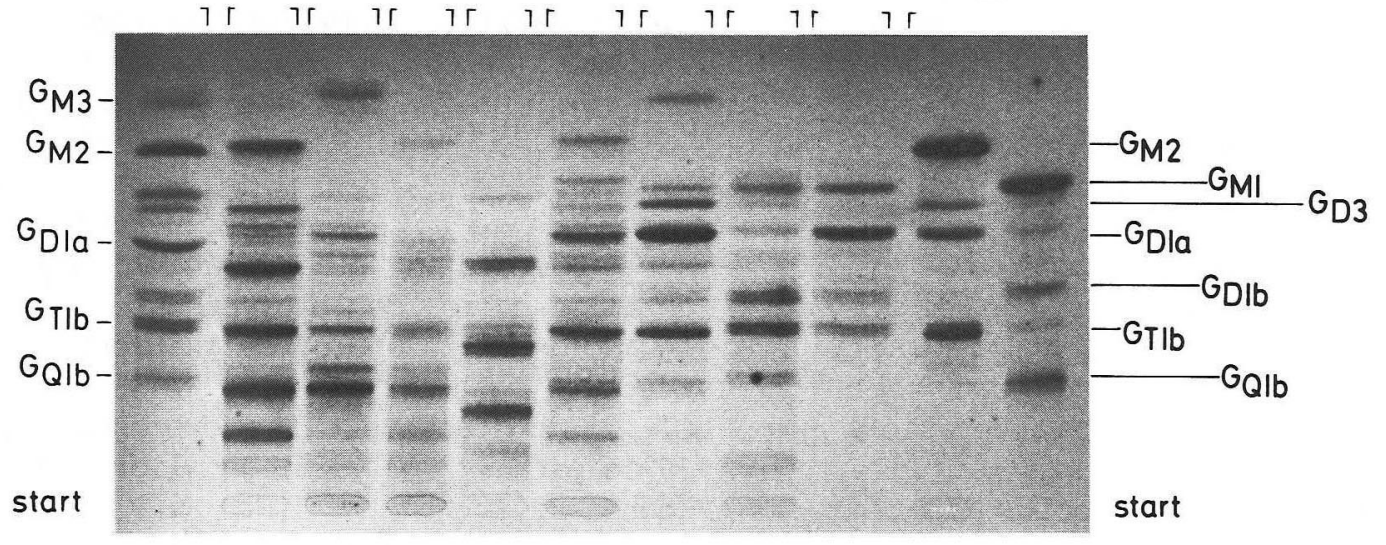

Fig. 3. Thinlayer chromatograms of brain gangliosides of 8 differently evolved vertebrates: decrease in number of fractions and polarity from fish to mammals. 
TIGG Vol.2 No.8 (1990)

MINIREVIEN (TIGG-11/02/90-MR-2)

which continues to adulthood, is proceeded by a second, smaller rise of $\mathrm{GD}_{3}$, probably due to oligodendroglial cell proliferation.

- Finally, during the phase of senescence, a continuous decrease of GDa, and by this a relative higher proportion of polysialogangliosides, may contribute to a change in the polarity (= rigidity) of the neuronal membranes.

These data revealing significant changes in the biosynthesis of individual ganglioside species during neurogenesis support the assumption that these glycosphingolipids contribute functionally to the various phases of nerve cell differentiation.

2.1.3. Neurological abnormalities of brain gangliosides (for review comp. 34-37)

Many neurological mutations affect specific stages of nervous system development. Attempts had been made to correlate alterations of differentiation of nerve cells during neurogenesis to abnormalities of gangliosides. Concerning this aspect laboratory rodents, especially mice, are useful models for such kind of investigations: In Jimpy mice mutant, being affected in myelin formation, the content of ganglioside-bound sialic acid is reduced. In the Quaking mutant, which is characterized by a major defect in myelin compaction, a pool of $\mathrm{GM}_{1}$ is particularly linked to myelin. The Trembler mutant affects mainly the peripheral nerves; it is associated with abnormal Schwann cell proliferation. The biosynthesis of $\mathrm{GD}_{3}$, which in normal cases is indicative for cell proliferation, in this mutant has not been evidenced. $\mathrm{GT}_{1}$ a has been found to be significantly reduced in mice mutations resulting in Purkinje cell degenerations in the cerebellum.

Similar as in humans, also in mice (and cat), lysosomal storage diseases (= gangliosidosis), resembling in some cases Niemann-Pick disease were detected, in which abnormal accumulations of $\mathrm{GM}_{2}, \mathrm{GM}_{1}$ or $\mathrm{GM}_{3}$ took place (comp. Fig. 2).

In summary these results concerning abnormalities in the biosynthesis of brain gangliosides (mutants in mice, gangliosidosis in humans) also clearly show that any disturbances in the formation of individual ganglioside species induce significant dysfunctions of neuronal processes.

2.2 Bio-electrical peculiarities of brain gangliosides (for review comp. 18)

As early as 1963 McIlwain (38) demonstrated that exogenously applied gangliosides can restore the excitability of brain slices to electrical pulses. Since then especially $\mathrm{Ca}^{2+}$ ganglioside-complexes are assumed to be essentially involved in the properties of excitation, transmission and storage of neuronal information. Several experiments have been carried out investigating the influence of neuraminidase and other compounds which might interfere with sialic acids and thereby change the bio-electrical activities of neurons. Results were obtained from single cell and summation potential measurements in vivo from spinal cord of frogs, optic tract of goldfish and from hippocampal and striatal slices of the rat and guinea pig. Especially the latter experiments revealed partly contradictory results, but it was concluded, that gangliosides play a functional role as neuromodulators for synaptic transmission possibly by modulating the activity of postsynaptic receptors.

In addition to these experiments the influence of exogenously administered gangliosides and other lipids on the electro-responsiveness of Aplysia 


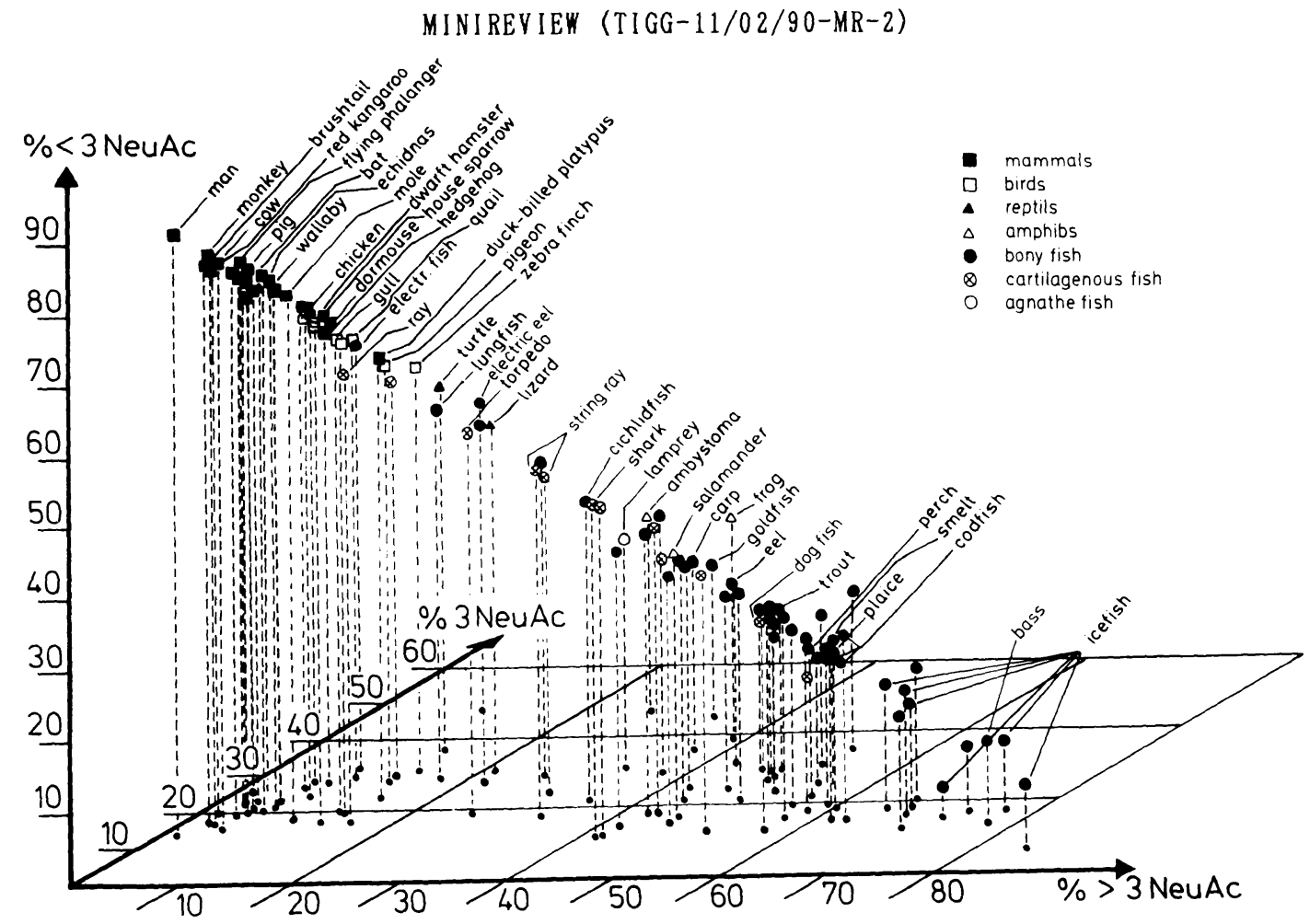

Fig. 4. Three-dimensional arrangement of brain gangliosides of about 100 representatives of vertebrates out of 6 classes with different temperature requirements. Plotting of relative composition of differently polar gangliosides containing 3 , less than three, and more than 3 negatively charged sialic acid residues. Antarctic icefish posses the most polar brain ganglioside pattern.

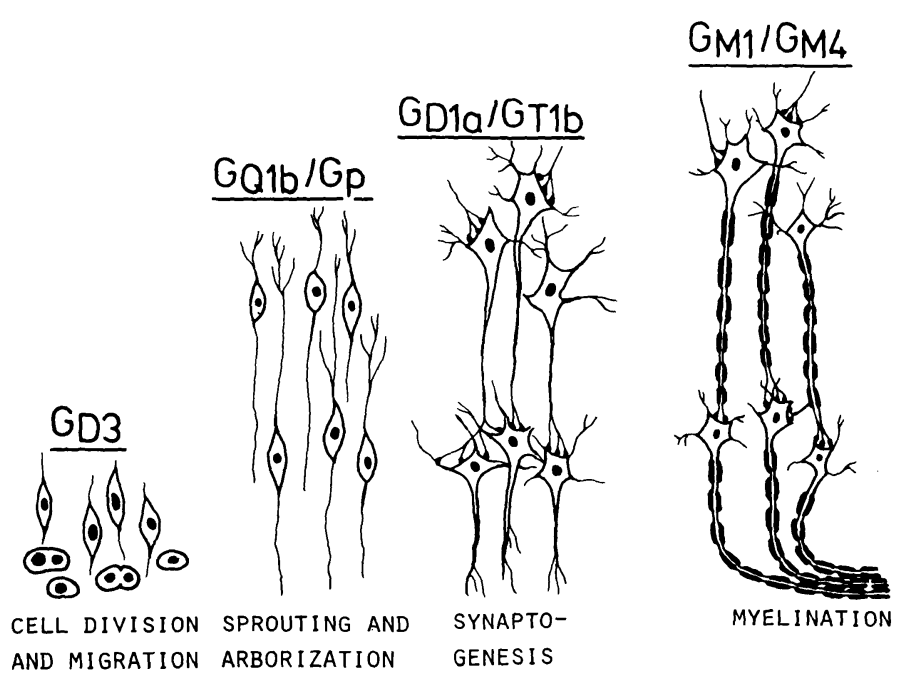

Fig. 5. Scheme of the marker function of brain gangliosides for the determination of the various developmental stages of neurogenesis (for nomenclature of gangliosides comp. Fig. 2) 


\section{TIGG Vol.2 No.8 (1990) \\ MINIREVIEW (TIGG-11/02/90-MR-2)}

neurons has been investigated using voltage clamp techniques $(39,40)$. Although Aplysia neurons themselves are devoid of sialic acid (and by this of gangliosides) very peculiar and immediate electrical responses following short-term applications $(0.1$ to 2.5 $\mathrm{sec}$ ) of gangliosides were found like depolarization of the membrane, desensitization following subsequent stimulation pulses, induction of biphasic responses from initial short outward to long-lasting inward current etc. These short-term responses could be interpreted as an expression of great functional affinity of gangliosides to the electro-responsiveness of biological membranes, which probably might be due to a specific interaction of the lipid with membrane carrier proteins.

Summarizing, from these data it can be concluded that gangliosides obviously interfere somehow with the electro-responsiveness of neuronal membranes, even in those cases, in which these compounds naturally do not exist.

2.3. Biochemical peculiarities of brain gangliosides (for review comp. 20)

The discovery of neuritogenic and/or neuronotropic properties of exogenous gangliosides for neuronal differentiation had been of great importance especially with regard to the question whether or not exogenously administered gangliosides might have beneficial effects on human neuropathia. It had been proven that exogenously added gangliosides can insert spontaneously into the cell membrane and behave in a manner that is indistinguishable from the membrane's natural gangliosides (37). When being administered directly to retina ganglion cells in situ a tritiated $\mathrm{GM}_{1}$ becomes incorporated into the cells, undergoes axonal transport to the synaptic terminals in the optic lobe, where it becomes incorporated into $\mathrm{GD}_{1 a}$ (41).

On this background it is of utmost importance that exogenous gangliosides indeed possess specific trigger or modulatory properties for various functional membrane proteins (channel proteins, ionic pumps, receptors) in synapses. Thus different gangliosides species were shown to act as modulators for the process of protein-phosphorylation insofar as they influence the activity of protein kinase C (42-45), Ca/calmodulin II $(46,47)$, Ca/gangliosides $(42,48,49)$, tyrosine kinase (50), Ca/phosphatase (calcineurin) (51), CaM/phosphodiesterase (51), CAMP/kinase (52) and adenylate cyclase $(53,54)$. Furthermore, gangliosides modulate the activity of different neuronal ATPases, like $\mathrm{Na}^{+} / \mathrm{K}^{+}$-ATPase, $\mathrm{Ca}^{2+}-\mathrm{Mg}^{2+}$-ATPase and $\mathrm{Ca}^{2+}$-ATPase (for review comp. 20). In the marmalian brain, for instance, the $\mathrm{Ca}^{2+}$-ATPase of synaptosomal fractions becomes most significantly activated by the addition of various gangliosides.

Summing up these biochemical data, it can be concluded that gangliosides can be regarded as to play a crucial role as trigger or modulatory substances for neuronal, especially synaptic membrane-bound processes like transmission and storage of information (see below).

2.4. Physico-chemical peculiarities of brain gangliosides (for review comp. 52-62)

While intracellular calcium in combination with $\mathrm{Ca}^{2+}$-binding molecules acts as a second messenger, the initiation of the electrochemical process of synaptic transmission requires first of all primary messenger systems at the outer membranes surface by which the influx of calcium from its extracellu- 
性が高いものからなっており、50\%のガング リオシドが4-7個のシアル酸残基を有している。 より高度に進化した恒温動物である鳥類や哺 乳類の脳のガングリオシドは、比較的少種類の、 ほとんどがガングリオテトラオースをコア構 造にもつ、より極性の低い種類 (GM1，GD1a， GD1b，GT1b)から構成されている(Fig. 3，4)。 これに加えて、系統発生的により新しい脊椎 動物（たとえば、哺乳類においては、嘴歯類 や食虫類にたいして雨長類）では、ガングリオ シドの脳各部位における分布状態を比較する とガングリオシド種の数が減少していること が見い出された。

脊椎動物の温度順応 (季節的温度变化に対す る気候順沁や実験的に仕組まれた温度の变化 に対する馴化）の研究から「理境昷度が下が るほど脳ガングリオシドのシアル酸付加（= 楆性）の程度が高くなる」という法則が生ま れた。部分的にはこの傾向は、より高い温度 に適応した動物の脳のガングリオシドの膜結 合性シアリダーゼに対する感受性の変化によ ってもたらされていることが見い出された。

要約すると、脊椎動物が系統発生的及び生 態生理学的に適応していくなかで脳ガングリ オシド濃度や組成が大きく変化するという事 実は、神経系をより効率的に構筑した結果と してこれらの脂質が選択されたのであるとい う仮説を支持するものである。

2.1.2. 個体発生的見地（総説は25-33参照）

脊椎動物の個体発生の間、脳のガングリオ シド形成に劇的な变化が生じる。それは、神 経の分化（=神释発生）のいろいろな段階と 関連しうる。個々のガングリオシドが神経細 胞の発育のある特定の段階と関連して発現さ れるという事実に限っていえば、ガングリオ シドは神経分化の程度を示すマーカー物質で あるといえる(Fig. 5)：

一神経やその前駆細胞が增殖期にあるとき は、GD3(とGD2)が主で、より複雑なガングリ オシドは存在しないという、比較的単純なガ ングリオシド組成を特徵としている。

一 細胞の移動と分化の時期には、GD3は急激 に減少してその代わり主にC生合成系に属す
るポリシアロガングリオシド(GT1c，GQ1c， GPIC，G*H”，G"S"，Fig. 2参照) が主とし て合成される。

一 神䅅㧴稚の增殖とシナブス形成の時期に は総ガングリオシドの生合成が数倍に增加 するのであるが、GD1aとGT1bが急激に増え るのが特徴的である.これと同時に、C合成 経路のポリシアロガングリオシドの発現は 減少する。

一 ミエリン形成がはじまるとGM1とGM4が增 加してくる。この成体期に続く最後の発育 期には、おそらく乏枝神経膠細胞の增殖に よるとみられるGD3の 2 度目の小さな增加が みられる。

一最後に老化期においては、GDlaの継続的 な減少とそのためにポリシアロガングリオ シドの割合が相対的に増加する。このことに よって、神経膜の極性（=㓮性）が変化す るのかもしれない。

神経発生において各ガングリオシド種の生 合成が有意に変化することを明らかにしたこ れらのデータは、これらのスフィンゴ糖脂質が 神経細胞の分化のさまざまな時期において機 能的に関わっているという仮説を支持するも のである。

2.1.3. 脳ガングリオシドの神経学的異常 (総 説は34-37参照)

多くの神経学的変異が特定の神経系の発有 の段階に影響を及ぼす。神経発生における神 経細胞の分化が变異することとガングリオシ ドに異常があることを関係づけるいくつかの 試みがなされた。この点からは、実験用の踤 歯類、特にマウスがこの種の観察には有効な モデルとなる：Janpy nice nutantではミエリ ンの形成に異常があるのだが、ガングリオシ ド結合性のシアル酸量が隇少している。 Quaking mutantではミエリンのコンパクショ ンに重大な欠陥があるのであるが、GM1がミエ リンに結合して蓄積している。Trabler mutantは主に末梢神経の異常であるが、シュ ワン細胞の異常增殖が関連している。正常な 場合には細胞の增殖を示すGD3の生合成は、こ の変異体では認められない。小脳のプルキニ 
TIGG Vol.2 No.8 (1990)

MINIREVIEW (TIGG-11/02/90-MR-2)

lar storage sites $\left(\mathrm{Ca}^{2+}=10^{-3} \mathrm{M}\right)$ into the synaptoplasm $\left(\mathrm{Ca}^{2+}=10^{-7} \mathrm{M}\right)$ is induced. Recently Rahmann and coworkers (63-65) could show by means of electro-spectroscopic imaging (ESI) and the application of gold-labeled monoclonal antibodies the distinct localization of extracellular calcium stores particularly within the synaptic cleft, of a high-affinity $\mathrm{Ca}^{2+}$-ATPase at the inner membranes of the very local zone of synaptic contact, and of ganglioside epitopes in a clusters arrangement at the outer leaflet of synaptic terminal membranes. This adds to the notion, that calcium indeed plays a central role in nerve related biological functions of the gangliosides.

This is one of the reasons, why the interest of research during the last few years has been focused more and more on the investigation of any specific physico-chemical peculiarities of gangliosides in their interaction with calcium which do not exist in other membrane lipids. The aim of this kind of research is to contribute to the elucidation of physico-chemical mechanisms demonstrating the possible functional involvement of gangliosides as neuromodulators.

From different physico-chemical studies analyzing the behavior of gangliosides in liposomes, in mono- and in bilayers as artificial and simple semi-membrane systems the following major results were obtained: The binding of calcium with gangliosides in bilayer (PC/G) is relative loosely (association constant $\mathrm{K}_{\text {ass }} 10^{2} / \mathrm{M}$ ), while in micellar configuration and at low ionic strength a higher binding had been observed (Kass $10^{4} / \mathrm{M}$ ). In liposomes and in micelles the calcium binding is discontinuous (break in the binding curve!).

In monolayer experiments pure gangliosides in comparison to phospho- lipids exhibit a higher compressibility and stability of the film, and a much higher negative head group potential. The addition of calcium induces a monolayer condensation, a significant rise of the film stability, a change of the molecular conformation and an alteration of electric properties (head group potential).

Mixed gangliosides - peptide (ion carrier valinomycin) monolayers show a higher miscibility and stronger molecular interaction than phospholipids and a formation of specific gangliosidepeptide complexes (molecular cavity effect). The addition of calcium induces phase separation and/or aggregate formation between ganglioside and peptide. - In mixed ganglioside gramicidin (= ion channel) bilayers an increased conductance of ion channels by gangliosides depending on the degree of sialylation can be stated.

In a polarography study the desorption potentials of ganglioside monolayers were measured revealing that the addition of calcium but not of magnesium stabilized the ganglioside film against its destruction induced by higher electrical field strength (cathodic shift).

Summarizing, the various physicochemical approaches reveal very peculiar properties of gangliosides especially in connection with calcium, which are almost unknown from other membrane lipids. These results can be taken as evidence for the assumption that gangliosides might fulfill peculiar functions in synaptic membranes, particularly with regard to alterations of their electro-responsiveness.

3. Model of the involvement of brain gangliosides as modulators for synaptic transmission and langterm neuranal adaptive processes (for review comp. 6,16-21) On the background of the physio- 
エ細胞の変性をきたす変異マウスではGT1aが 有意に減少していることが見い出された。

ヒトと同じく、マウス（とネコ）でもいくつ かの例でNiemann-Pick病に似通ったリソソー 厶蓄積症（ガングリオシドーシス）が見い出 された。この場合GM2, GM1，またはGM3が異常 に蓄積していた（Fig．2参照）。
要約すると、脳ガングリオシドの生合成異 常（変異マウス、ヒトのガングリオシドーシ ス）に関するこれらの結果は、個々のガング リオシド種の合成が阻害されれば神経作用に 何らかの機能障害が起こることを明らかにし ている。
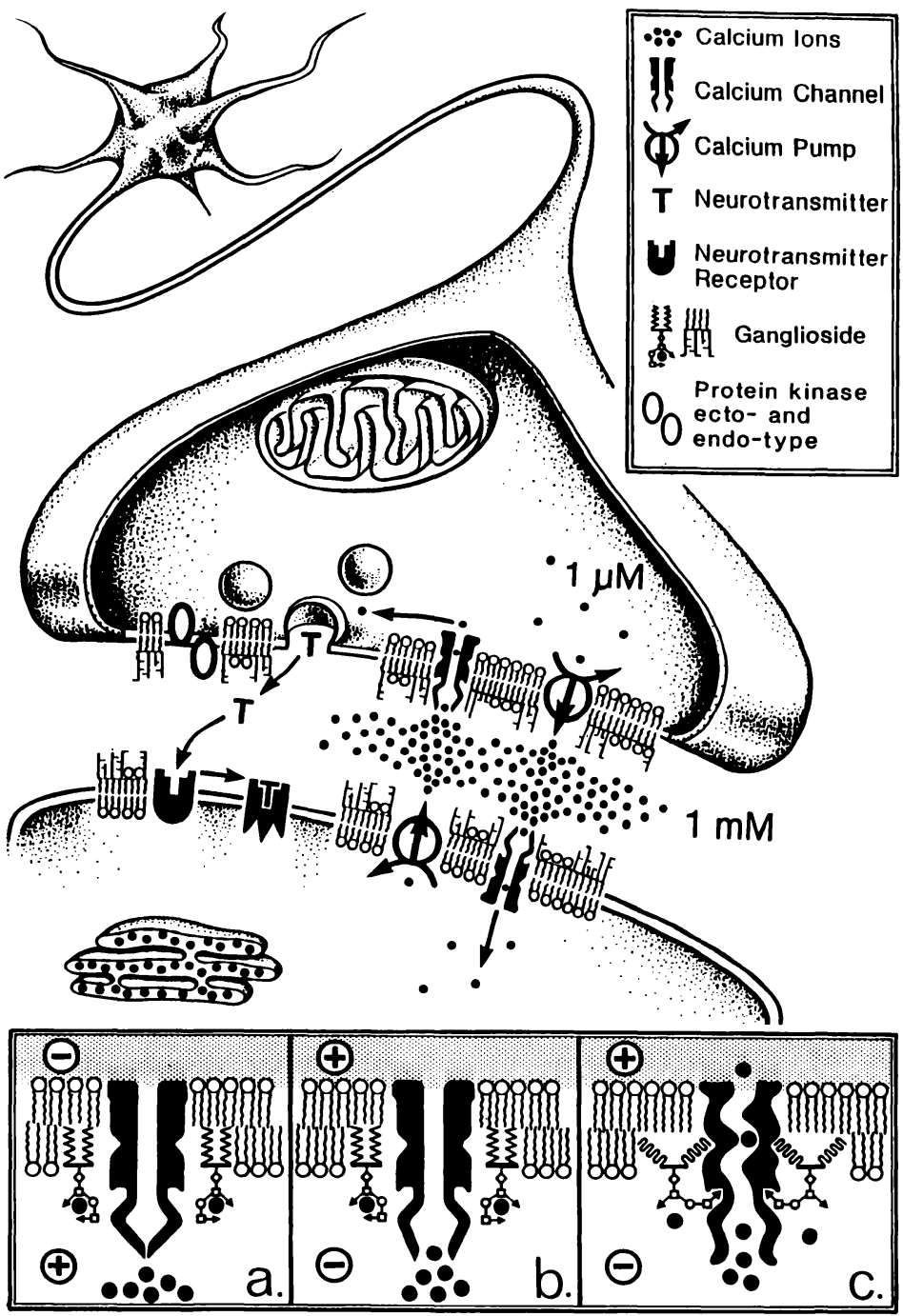

Fig. 6. Scheme of symaptic terminals indicating the localization of gangliosides, calcium and membrane-bound functional proteins. a-c: modulation of a voltage-dependent $\mathrm{Ca}^{2+}$-channel by gangliosides 


\section{MINIREVIEN (TIGG-11/02/90-MR-2)}

logical, biochemical and physico-chemical data concerning peculiar properties of brain gangliosides their possible functional role in the short-term process of symaptic transmission and in long-lasting neuronal adaptive events can be discussed already quite precisely. This is due to the fact that on the one side by means of newly developed electronmicroscopic techniques a precise ultrastructural localization of calcium, of a high-affinity $\mathrm{Ca}^{2+}$ ATPase and of gangliosides in clustered form within the very local zone of synaptic contact had been shown. On the other side by mean of physicochemical investigations with mono- and bilayers as artificial semi-membrane systems distinct effects of calcium on lipid - peptide-interactions (phase separation effect) had been demonstrated (Fig. 6). On this basis the following phases of ganglioside involvement in synaptic events can be discussed (Fig. 7 and 8 ):

- During neuronal maturation and differentiation (neurogenesis) significant changes in content and composition of brain gangliosides occur indicating that these lipids fulfill specific tasks concerning neuronal cell-to-cell recognition, cell-to-cell contact and fiber growth.

- Before formation of definite synapses, during which nerve fiber terminals establish loose contacts only, $\mathrm{Ca}^{2+}$-ganglioside-complexes are assumed to be arranged in the outer membrane leaflets of the fiber terminals in a still disordered form (Fig. 7,1). The membranes are kept rigid by these complexes, and by this are "tightened" for substance permeation (Fig. 8a).

- Following first functional activation (= transmission) local changes in ion concentration and/or changes in the electrical field strength at the outer membrane surface can cause an ordered arrangement of the gangliosides by means of conformational changes of the $\mathrm{Ca}^{2+-g a n g l i o s i d e-~}$ complexes and a release of $\mathrm{Ca}^{2+}$ from the negative sialic acid binding sites of gangliosides. The voltage dependent influx of calcium into the symapse fulfills the function of a primary messenger for the internalization of the electrically coded information. By the release of calcium from the ganglioside binding sites the very local zone of synaptic membrane becomes more fluid, causing an alteration of membrane permeability for calcium (Fig. 8b). The intrasynaptic calcium now can induce second messenger cascades, thus triggering the transmitter release (Fig. 8c-e), and by this the activation of the postsynaptic membrane. Here gangliosides were found to modulate receptor molecules and due to this the depolarization of the postsynaptic membrane.

- Finally during repolarization the resting potential is being restored by the re-organization of ion-balance by activation of ion pumps, enzymatic degradation and/or reuptake of parts of the transmitter. $\mathrm{Ca}^{2+}$ is pumped out from the synaptoplasm by means of the gangliosidemodulated, membrane-bound $\mathrm{Ca}^{2+}$ ATPase. At the cell surface calcium induce phase separation between gangliosides and the ion-channel proteins and by this tightening the membrane for a new transmission cycle (Fig. 6a-c, 8f).

- In case of long-term neuronal events, like memory formation, the formation of short-term memory following intensive neuronal stimulation might be induced by the modulation of membrane-bound func- - 


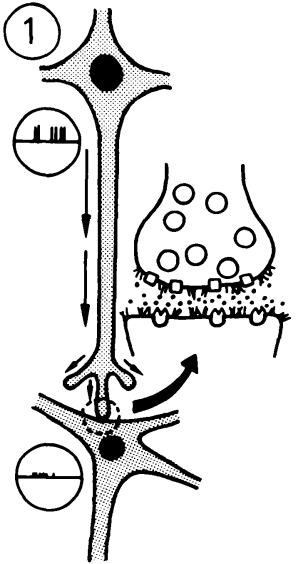

before stimulation

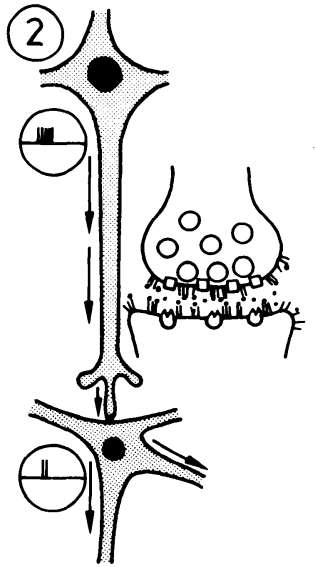

first stimulation $\rightarrow$ labile synapse

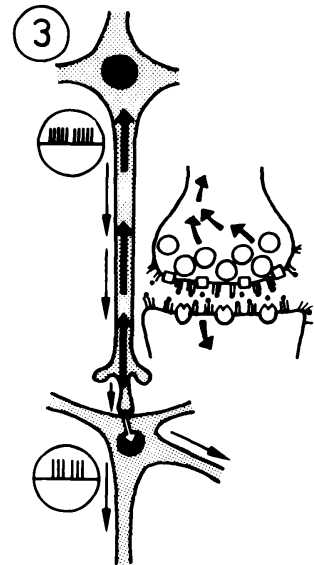

multiple stimulation $\rightarrow$ molecular feedback. onstet of retrograde transport

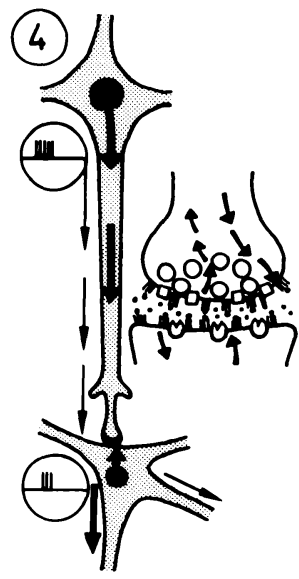

long-term stabilization by anterograde transport and further feedback

Fig. 7. Functional scheme of the long-term neuronal adaptation by means of molecular facilitation in synapses with gangliosides (for details comp. text and Fig. 8)

a.

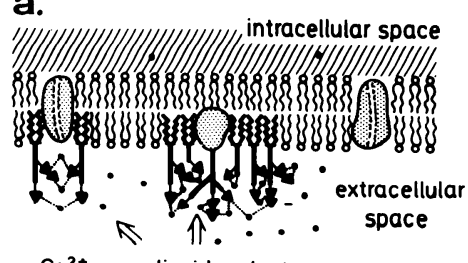

$\mathrm{Ca}^{2+}$-ganglioside-cluster

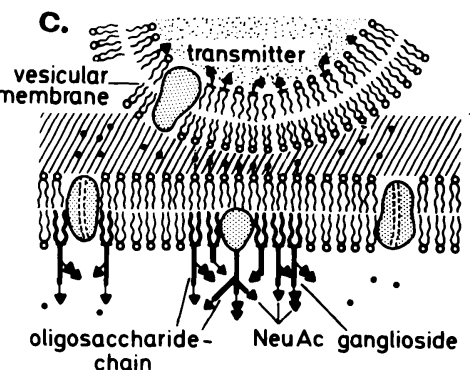
chain

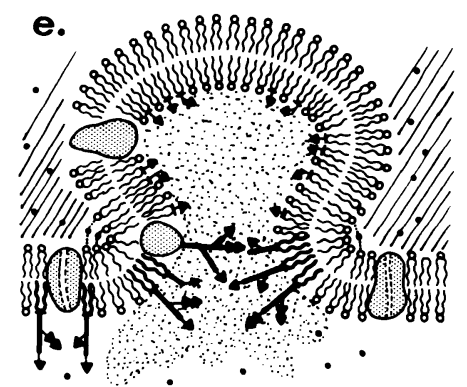

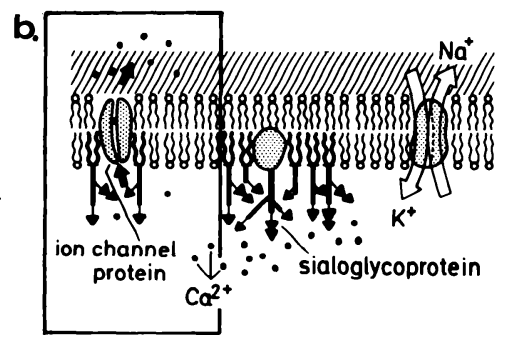

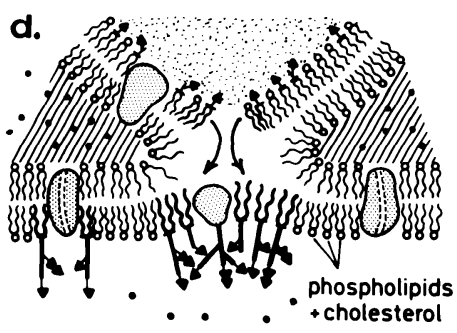

Fig. 8. Functional model of the involvement of gangliosides in synaptic transmission at the very local zone of the presynaptic membrane (comp. Fig. 1)

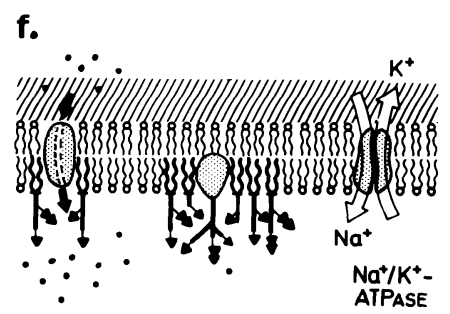


TIGG Vol.2 No.8 (1990)

MINIREVIEN (TIGG-11/02/90-MR-2)

tional proteins in the pre- and postsynaptic terminals such as protein kinases, ATPases, adenylate-cyclase and receptors (Fig. 6).

- Formation of intermediate memory might occur by activation of second messenger systems within both synaptic terminals and the onset of a molecular feed-back to the nerve cell bodies on the basis of the retrograde neuronal transport (Fig. $7,3)$.

- The formation of long-term memory will occur following repeated stimulation and subsequent supply of synaptic membrane with modified compounds being necessary for synapse stabilization and greater efficacy of membrane-bound functional molecules. The substances are being delivered to synaptic terminals by activation of effector and regulator genes within the perikaryon following anterograde transport of newly synthesized compounds from cell bodies to synaptic terminals. Thus the formation of a modulated zone of synaptic contact represents the structural basis of a facilitated pathway between interacting neurons.

In warm- verses cold-blooded vertebrates the "cocktail" of gangliosides being used as modulators for synaptic membrane-bound functional proteins is being composed by ganglioside species, thus guaranteeing homoviscosity of the very local zone of the membrane in adaptation to different environmental temperatures: comp. chapter 2.1.1.)

\section{References}

1. Yamakawa, T. (1987) in NATO ASI Series H7, Gangliosides and modulation of neuronal functions, Rahmann, H. (ed.), pp 3-15, Springer-Verlag, Berlin-Heidel-

\section{berg}

2. Hilbig, R., and Rahmann, H. (1987) in NATO ASI Series H7, Gangliosides and modulation of neuronal functions, Rahmann, H. (ed.), pp 333-350, Springer-Verlag, BerlinHeidelberg

3. Dennis, R.D., Geyer, R., Egge, H., Peter-Katalinic, J., Keller, M., Menges, H., and Wiegandt, $H$. (1987) in NATO ASI Series H7, Gangliosides and modulation of neuronal functions, Rahmann, $\mathrm{H}$. (ed.), pp 351-358, SpringerVerlag, Berlin-Heidelberg

4. Rahmann, H. (ed.): Gangliosides and Neuronal Functions. NATO ASI Series H7, pp 650, SpringerVerlag, Berlin-Heidelberg

5. Ando, S. (1983) Neurochem. Intern. 5, 507-537

6. Rahmann, H. (1983) Neurochem. Intern. 5, 539-547

7. Rahmann, $\mathrm{H}$, , and Wiegandt, $\mathrm{H}$. (1990) NATO ASI Series (in press)

8. Mahadik, S.P., and Karpiak, S.K. (1988) Drug Dev. Res. 15, 337-360

9. Massarotti, M., Marchesan, R., Matano, A.M.R., Petterson, P., and Rovigatti, A. (1988) J. Kuwait Med. Assoc. 22, 225-235

10. Nakamura, M., and Saito, M. (1990) TIGG 2, 33-39

11. Spiegel, S., and Buckley, N.E. (1990) TIGG 2, 100-105

12. TAki, T., and Handa, S. (1990) TIGG 2, 182-188

13. Ledeen, R.W. (1984) J. Neurosci. Res. 12, 147-159

14. Mandel, P. (1987) in NATO ASI Series H7, Gangliosides and modulation of neuronal funcitons, Rahmann, H. (ed.), pp 601-611, Springer-Verlag, Berlin-Heidelberg

15. Rahmann, H. (1976) Neurobiologie, pp 273, UTB-Verlag, Eugen Ulmer, Stuttgart 
2.2. 脳ガングリオシドの生物電気的特性（秴 説は18参照)

1963年にMcII wainは、外から加えたガングリ オシドが脳の薄片の電気パルスに対する興索 性を回復させることを示した(38)。それ以来、 とくにCa ${ }^{2+}$ ーガングリオシド複合体が、興套や 伝達、神経情報の蓄積においてひとつの要素 となっていると考えられている。シアリダー ゼやシアル酸に干涉するようなほかの物質を 用いて、ニューロンの生物绳気的活動に变化が 起きるかどうかをみるいくつかの実験が行わ れた。1 個の細胞、カエルの脊噵、キンギョ の視索のようなin vivoの電位測定、ラットや モルモットの海馬や線維束の薄片を用いた実 験等から結果が得られた。特に後者の実験で は部分的に矛盾した結果が出たが、ガングリ オシドが、おそらく後シナプス受容体の活動を 調節することによって、神経調節因子として機 能的な役割を果たしていることが結論された。

これらの実験に加えて、外から加えたガン グリオシドや他の脂質がナメクジのニューロ ンの奄気反応性にどのように影辢するかが、 Vol tage clamp法によって観察された(39，40)。 ナメクジのニューロン自体はシアル酸を欠い ている（当然ガングリオシドす欠く）にすか かわらず、ガングリオシドをごく短時間付加 しただけで、非常に特徵的な索早い反応がみ られた。それはまるで、膜の脱分極、後続のパ ルス刺激に対する非反応性、初期の短い外向 きの電流に続いて持続的な内向きの電流を生 じる等々という二相性の反応の生成そのもの であった。これらの短時間の反応は、ガングリ オシドが生体膜の電気反応性に対して機能的 に大きく関与していると解积させうるるので あろう。そしてそれは恐らくガングリオシド と膜の輸送蛋白質との特異的な反応によって いるのであろう。

要約すると、これらのデータからガングリ オシドは、それが自然には存在しない系におい てさえも、明らかに神経細胞膜の電気反応性に 何らかの形で関わっていることが結論された。

\section{3. 㭚ガングリオシドの生化学的特性（铪}

\section{は20参照)}

神経の分化において外から加えたガングリ オシドが軸索の伸長作用や、もしくは神経栄 養因子としての性質を有しているという発見 は、特に、外部より投与したガングリオシド がヒトの神経疾患に有益な効果があるのかど うかという問題に関して非常に重要なことで あった。外から与えられたガングリオシドが 自動的に細胞膜に取り込まれ、膜に元々ある ガングリオシドと区別がつかない状態となる ことが証明されている(37)。トリチウム標識 したGM1を網膜の神経節に直接投与すると、そ れは細胞に取り込まれ、軸索輸送によって二対 体のシナプス末端まで到達し、そこでGD1aと なる(41).

こうした背景があるので、外から加えたガ ングリオシドがシナプスにおいていろいろな 機能を持つ膜蛋白質 (チャンネル蛋白質、イオ ンポンプ、受容体）に対して特異的な引き金 としての作用や調節作用を実際に持っていた という事実は極めて重要である。こうして、 種々のガングリオシド種がプロテインキナー ゼC(42-45)、Ca/カルモジュリン II(46，47)、 $\mathrm{Ca} /$ ガングリオシド(42，48，49)、チロシンキ ナーゼ(50)、Ca/フォスファターゼ（カルシニ ユリン) (51)、cAMP/キナーゼ(52)、アデニレー トサイクラーゼ(53、54)の活性に影響を及ぼ すという限りにおいては、これらガングリオ シドが蛋白質リン酸化の調節因子として働く ということが示された。さらに、ガングリオ シドは、Nat/K+-ATPase、 $\mathrm{Ca}^{2+}-\mathrm{Mg}^{2+}$-ATPaseや $\mathrm{CaR}^{2+} \mathrm{ATP}$ aseの様な種々の神経性のATPaseの活 性を調節する（総説は20参照）。たとえば、 哺乳類の脳では、シナプトゾーム画分のC ${ }^{2+}$ -ATPaseが種々のガングリオシドの添加によっ て最も効果的に活性化される。

これら生化学的情報を要約すると、ガング リオシドは神経系、特に、伝達や情報の蓄積 といったシナプス膜上で進し過程に対して引 き金または調節因子として決定的な役割を演 じているといえょう。

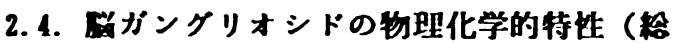


TIGG Vol.2 No.8 (1990)

MINIREVIEN (TIGG-11/02/90-MR-2)

16. Rahmann, H., RÖsner, H., and Breer, H. (1976) J. Theor. Biol. 57, 231-237

17. Rahmann, H., Probst, W., and MUhleisen, M. (1982) Japan J. Exper. Med. 52, 275-286

18. Rahmann, H. (1987) in NATO ASI Series H7, Gangliosides and modulation of neuronal functions, Rahmann, H. (ed.), pp 501-521, Springer-Verlag, Berlin-Heidelberg

19. Rahmann, H., and Rahmann, M. (1988) Das Geduchtnis - Neurobiologische Grundlagen, pp 320, J.F. Bergmann-Verlag, Mllnchen

20. Rahmann, H., (1989) in Progress in Zoology 37, Fundamentals of memory formation: Neuronal plasticity and brain function, Rahmann, H. (ed.), pp 349-368, G. Fischer-Verlag, Stuttgart-New York

21. Rahmann, H. (1983) in Neuronal Transmission and Memory, Caputto, R., and Marsan, C.A. (eds.) pp 159-177, Raven Press, New York

22. Rahmann, H. (1987) in: Life in Water and on Land, Dejours, P., Bolis, L., Taylor, C.R., and Weibel, E.R. (eds.) pp 433-446, Liviana-Press, Padova

23. Rahmann, H., and Hilbig, R. (1989) in: Thermal Physiology, Mercer, J.B. (ed.) pp 615-621, Elsevier Sci. Publ., Amsterdam-New YorkOxford

24. Rahamann, H., Hilbig, R., KOrtje, K.H., and Beitinger, H. (1959) in: Living in the Cold II, Malan, A., Cauguilhem, B. (eds.), Colloque INSERM pp 193-201, John Libbey EUROTEXT, London-Paris

25. Suzuki, K. (1965) J. Neurochem: 12, 969-979

26. RUsner, H. (1975) J. Neurochem. 24, 815-816

27. Breer, H., and Rahmann, H. (1977)
Roux's Arch. Dev. Biol. 181, 6572

28. Hilbig, R., RUsner, H., Merz, G., Segler-Stahl, $\mathrm{K}_{\bullet}$, and Rahmann, H. (1982) Roux's Arch. Dev. Biol. $191,281-284$

29. Hilbig, R., Lauke, G., and Rahmann, H. (1983/84) Dev. Neurosci. $6,260-270$

30. RUsner, H. (1982) Brain Res. 236, 49-61

31. Seybold, U., and Rahmann, H. (1985) Dev. Brain Res. 17, 201208

32. Seybold, V., and Rahmann, H. (1985) Roux's Arch. Dev. Biol. $194,166-172$

33. RÜsner, H., and Rahmann, H. (1987) in: NATO ASI Series H7, Gangliosides and modulation of neuronal functions, Rahmann, $\mathrm{H}$. (ed.), pp 373-390, SpringerVerlag, Berlin-Heidelberg

34. Suzuki, K. (1987) in NATO ASI Series H7, Gangliosides and modulation of neuronal functions, Rahmann, H. (ed.), pp 531-546, Springer-Verlag, Berlin-Heidelberg

35. Baumann, N.A., Harpin, M.L., Baron van Evercooren, A., Iwamori, M., and Maurin, Y. (1987) in NATO ASI Series H7, Rahmann, H. (ed.), pp 391-407, Springer-Verlag, BerlinHeidelberg

36. Fredman, P. (1987), in NATO ASI Series H7, Rahmann, H. (ed.), pp 435-444, Springer-Verlag, BerlinHeidelberg

37. Sandhoff, K., and Schwarzmann, G. (1989), in Progress in Zoology 37, Fundamentals of Memory Formation: Neuronal Plasticity and Brain Function, Rahmann, $\mathrm{H}$. (ed.), pp 229-239, G. FischerVerlag, Stuttgart-New York

38. McIlwain, H. (1963) Chemical exploration of the brain: a study 


\section{説は、52-62参照)}

細胞内のカルシゥムはC $\mathrm{a}^{2+}$-結合性の分子と 結合することによって第 2 番目のメッセンジ ヤ一として働くが、シナプス伝達 の電気化学 的過程の開始には、まずカルシウムをその細胞 外の眝蔵部位 $\left(\mathrm{Ca}^{2+}=10^{-3} \mathrm{M}\right)$ からシナプス細胞 質 $\left(\mathrm{Ca}^{2+}=10^{-7} \mathrm{M}\right)$ に流入させる膜の外側表面に ある第 1 番目のメッセンジャ一機構が必要で ある。最近Rahmannらは(63-65)、electrospectroscopic imaging(ESI)の手法と金で標 識したモノクローナル抗体を用いて、細胞外 のカルシウム眝蔵箇所は特にシナプス裂のな かに、高親和性 $\mathrm{Ca}^{2+}$-ATPaseはシナプス接合の 極めて限局された部位の内側の膜に、ガング リオシドのエピトープは塊となってシナプス 末端の膜の外側に各々局在していることを示 した。このことは、カルシウムがガングリオ シドの生物学的機能において実際に中心的な 役割を担っているという概念を付加する。

このことが、個々数年間の研究がガングリ オシドの他の膜の脂質にはないカルシウムと の反応性という物理化学的特性の観察に注が れた一つの理由である。この種の研究の目的 は、ガングリオシドの神経調節因子としての 機能の発現の物理化学的な機構を説明するこ とにある。

人工的な単純な膜系としてのリポソーム、 単層膜及び 2 層膜におけるガングリオシドの 挙動を調べる物理化学的な研究から次のよう な主な結果が得られた。カルシウムとガンク リオシドの耛合は 2 層膜内 $(\mathrm{PC} / \mathrm{G})$ では比较的 弱い（結合定数 $K_{\alpha} 10^{2} / \mathrm{M}$ ) が、ミセル形状を とり低イオン強度の下ではより強い結合が観 察された（Ka 104/M）。リポソームやミセル 中ではカルシゥムの結合は非連秸的である

（結合曲線がとぎれる！）。

単首腃の実駼において、精製されたガング リオシドは、リン脂質に比較して高い膜の圧 縮性と女定性を示し、非常に高い陰性頭部基 電位を示した。カルシウムを加えると、単首 膜の凝結、膜の安定性の上昇、分子形態の变 化と電気特性（頭部基電位）の変化をるたら した。
ガングリオシドーペプチド（イオンキ+リア 一であるバリノマイシン）の混合単層膜は、 リン脂質に比べて高いmiscibility（混合され 易さ）と強い分子間の相互作用を示し、特異 的なガングリオシドーペプチド複合体を形成 する（分子空洞効果）。カルシウムを加える と相分離と、または、ガングリオシドとぺプ チドの間で疑集塊を形成する。ガングリオシ ドーグラミシジン（=イオンチャンネル）の混 合 2 層腃においてはシアル酸の付加の度合に 応じてイオンチャンネルの伝導度が増加する。 ポーラログラフィーによってガングリオシ ド単層膜のdesorption potentialを測定する ことによって、カルシゥムがガングリオシド 膜に、高い電場強度（陰極シフト）による破壊 作用に対する安定性を与え、マグネシウムに はその効果がないことが明らかにされた。

要約すると、さまさまな物理化学的手法に よって、ガングリオシドの特に他の膜脂質で は殆どみられないカルシウムとの協調という 非常に特徵的な性質が明らかになった。これ らの結果は、ガングリオシドが特にシナプス膜 の電気反応性を変化させるということに関し ては、そこで独特の機能を果たしているとい う仮説を証明しているといえよう。

\section{3.悩ガンクリオシドのシナブス伝達及び長 期神释通度遏程に対する調第因子として のモデル（轱説は6，16-21参照）}

脳ガングリオシドの特性に関する生理学的、 生化学的、物理化学的データを背景として、 そのシナプス伝達の短時間の過程及び長期に 及ぶ神経適応の過程における機能的役割に関 してはすでにかなり正確に論ずることができ る。それは一方では、新たに開発された電子 顕微鏡の技法によって得られた、カルシウム、 高親和性 $\mathrm{Ca}^{2+}$-ATPaseとガングリオシドがシナ プス接合の極めて限定的な部位に固まって存 在しているという正確なデータに負うすので ある。他方では、単層膜や 2 層膜などの人工 的な膜系を用いた物理化学的観剧によって、カ ルシゥムの脂質-蛋白質相互作用に対する独特 の効果（相分離効果）が示されたことに負っ 


\section{TIGG Vol.2 No.8 (1990) \\ MINIREVIEN (TIGG-11/02/90-MR-2)}

of cerebral excitability and ion movement. Elsevier Amsterdam

39. Bưsselberg, D., Evans, M.L., Carpenter, D.O., and Rahmann, $\mathrm{H}$. (1989) Membr. Biochem. 8, 19-26

40. Bllsselberg, D., Carpenter, D.O., Sugita, M., Araki, S., Satake, M., and Rahmann, H. (1990) Biomed. Res. 11, 77-86

41. Willibald, C.J., Rösner, H., Schwarzmann, G., Sandhoff, K., and Rahmann, H. (1988) Neurosci. Res. 5, 361-379

42. Yu, R.K., Koerner, T.A.W., Demou, P.C., Scarsdale, J.N., and Prestegard, J.M. (1984) Adv. Med. Biol. 174, 87-102

43. Momoi, T. (1986) Biophys. Biochem. Res. Commun. 138, 865-871

44. Kreutter, D., Kim, J.H., Goldenring, J.R., Rasmussen, H., Ukomadu, C., DeLorenzo, R.Z., and Yu, R.K. J. Biol. Chem. 262, 16331637

45. Kim, J.Y.H., Goldenring, J.R., DeLorenzo, R.J., and Yu, R.K. (1986) J. Neurosci. Res. 15, 159166

46. Goldenring, J.R., Otis, L.C., Yu, R.K., and DeLorenzo, R.J. (1985) J. Neurochem. 44, 1229-1234

47. Fukunaga, K., Miyamoto, E., and Soderling, T.R. (1990) J. Neurochem. 54, 102-109

48. Nagai, Y., and Tsuji, S. (1988) in: New Trends in Ganglioside Research: Neurochemical and Neuroregenerative Aspects, Ledeen, R.W., Hogan, E.L., Tettamanti, G., Yates, A.J., and Yu, R.K. (eds.) pp 329-350, Liviana Press, Padova

49. Chan, K.F.J. (1988) J. Biol. Chem. 263, 568-574

50. Bremer, E.G., Hakamori, S., BowenPope, D.H., Raines E., and Ross, R. (1984) J. Biol. Chem. 259, 6818-6825

51. Yates, A.J., Markowitz, D.L.,
Doreen, L., stephens, R.E., Pearl, D.K., and Ronald, L. (1988) Exp. Neurol. 47, 119-127

52. Yates, A.J., Walterts, J.D., Wood, C.L., and Johnson, J.D. (1989) J. Neurochem. 53, 162-167

53. Partington, C.R., and Daily, J.W. (1979) Mol. Pharmacol. 15, 484491

54. Berry-Kravis, E., and Dawson, G. (1985) J. Neurochem. 45, 17391747

55. Maggio, B., Sturtevant, J.M., and Yu, R.K. (1987) BBA 901, 173-182

56. Maggio, B., Cumar, F.A., and Caputto, R. (1981), BBA 650, 6987

57. Probst, W., Mbbius, D. and Rahmann, H. (1984) Cell. Molec. Neurobiol. 4, 157-176

58. Probst, W., and Rahmann, H. (1987) in NATO ASI series H7, Gangliosides and Modulation of Neuronal Functions, Rahmann, H. (ed.), pp 139-154, Springer-Verlag, BerlinHeidelberg

59. Beitinger, H., Probst, W., Möbius, D., and Rahmann, $\mathrm{H}$. (1987) J. Biochem. 102, 963-966

60. Schifferer, F., Beitinger, H., Rahmann, H., and Mobbius, D. (1988) FEBS Lett. 233, 158-162

61. Beitinger, H. Vogel, V., Mbbius, D., and Rahmann, H. (1989), BBA 984, 293-300

62. Wobrner, M., Greiner, G., Rau, H., and Rahmann, H. (1988) Ber. Bunsenges. Phys. Chem. 92, 582589

63. Seybold, V., RUsner, H., Greis, C., Beck, E., and Rahmann, H. (1989) J. Neurochem. 52, 19581961

64. KOrtje, K.H., Freih\&fer, D., and Rahmann, H. (1990) J. Histochem. Cytochem. 38, 895-900

65. KOrtje, K.H., Freihbfer, D., and Rahmann, H. (1990) Ultramicroscopy $32,12-17$ 
ている(Fig. 6)。これに基づいて、シナプス の活動におけるガングリオシドの関わりにつ いて次に考察していきたい(Fig.7，8)。

- 神柽の成熱及び分化期（神释耭発生）に おいては脳ガングリオシドの含有量と組成 に有意な変化がみられ、このことは、ガン グリオシドが神経系の細胞間認識、細胞間 接着及び絾維の成長に関して特異的な役目 を果たしていることを示している。

一明磪なシナブスを形成する前の即階、こ の間は神経瀻維の末端は緩く接合し合って いるに過ぎないが、Ca ${ }^{2+}$ ーガングリオシドー 複合体は、まだ無秩序な形態をとって繊維 末端の膜の外側表面に集められていると考 えられる(Fig，1，7)。膜はこれら複合体に よって堅く保たれ、これによって物質は膜 を透過しにくくなっている(Fig. 8a)。

一最初の機能的活性化（=云速）に続く、 外側の膜の表面におけるイオン濃度の局所 的な変化や、または、電場強度の变化は、 $\mathrm{Ca}^{2+}$-ガングリオシド-複合体の形態の变化 やCa ${ }^{2+}$ のガングリオシド結合部位である陰 性シアル酸からの放出によってガングリオ シドの定められた配列を引き起こす。カル シウムのシナプスへの電压依存性の流入が、 電気的に符号化された情報の内面化のため の第一番目のメッセンジャーとしての機能 を果たす。ガングリオシドの結合部位から のカルシウムの放出によって、シナプス膜 の非常に局所的な部位の流動性が增し、カ ルシゥムに対する膜の透過性に変化を起こ す(Fig. 8b)。シナプス内のカルシゥムはそ こで第二番目のメッセンジャーのカスケー ドを動かし、そうして伝達物質放出の引き 金が引かれ（Fig. 8c-e)、そしてこのことに よって、シナプス後膜の活性化が起こる。 ここではガングリオシドは受容体分子を調 節し、こうしてシナプス後膜の脱分極を調 節していることが見い出されている。

一最後に再分楆の既陼では、イオンポンプ の活性化、伝達物質の醉索的分解や、または、 再摃取によってイオン平衡の再構築が行わ
れ静止電位が再現される。Ca ${ }^{2+}$ はガングリ オシドによって調節されている膜結合性の $\mathrm{Ca}^{2+}$-ATPase によってシナプスの細胞質か ら汲出される。細胞表面においては、カル シゥムがガングリオシドとイオンチャンネ ル蛋白質の間の相分離を引き起こし、この ことによって次の伝達サイクルに備えて膜 を堅くする(Fig. 6a-c，8f)。

一記憶の形成のような長期の神经作用に関

しては、強い神経刺激に続く短期間の記憶 は、蛋白質リン酸化醅素、ATPase、アデニレ ートサイクラーゼや受容体のような前シナ プス及び後シナプス末端の膜結合性の機能 性蛋白質を調節することによって引き起こ されるのであろう(Fig. 6)。

一 中期間の記境の形成は、シナプス両末端 における第二番目のメッセンジャ一系の活 性化及び、逆行性の神経伝達に基づく神経 細胞への分子的フィードバックの開始によ

って起こるのであろう(Fig. 7,3)。

一長期間の記滰の形成は、刺激の繰り返しと、 それに続いてシナプスを安定化するために 必要な物質及び、より強力な作用を持つ膜結 合性の機能性蛋白質をシナプス膜に供給す ることにより行われるのであろう。それら 物質は、核周囲部で作用物質之調節物質の 遗伝子が活性化されることにより合成され、 続いて、新しく合成された物質は、細胞体 から前方輸送されてシナプス末端に集めら れる。このように、シナプス接合の調節部 位の形成は、ニューロン間の相互作用を容易 にするための檴造的な基礎となっている。

温血及び冷血脊椎動物を比較すると、シナ プス膜結合性機能性蛋白質の調節因子として 使われているガングリオシドの組成は、異な る環境温度に適応する上で臑めて局所的 な部位の枮性を均一に保つことが可能なよう に、適切に構成されている(2.1.1. 章参照)。

三菱化成生命科学研究所・複合榶質研究室 東 秀好 訳 
TIGG Vol.2 No.8 (1990)

MINIREVIEN (TIGG-11/02/90-MR-2)

trend can be registered indicating a decrease of the concentration from the phylogenetically younger regions (forebrain) to the older structures (spinal cord).

The brain ganglioside composition in the cold-blooded lower vertebrates consists mainly of a larger number of polar fraction components based on lactose-, gangliotriaose- or gangliotetraose- carbohydrate core (Fig. 2). Concerning this, in antarctic icefish the brain ganglioside composition had been shown to consist of the most polar pattern among the animal kingdom and being composed of about 50\% of ganglioside species containing 4 to 7 sialic acid residues. In the higher evolved warm-blooded birds and mammals the brain ganglioside pattern is being composed mainly of a smaller number of less polar species $\left(\mathrm{GM}_{1}, \mathrm{GD}_{1 \mathrm{a}}, \mathrm{GD}_{1} \mathrm{~b}\right.$, $\left.\mathrm{GT}_{1 \mathrm{~b}}\right)$ mostly from the gangliotetraosefamily (Fig. 3,4). In addition to this, in phylogenetically younger vertebrates (e.g. primates among the mammals verses rodents or insectivores) a trend to a topographic, that means to a brain region-specific diversity of the ganglioside pattern, combined with a reduction in the number of individual ganglioside species was found.

Following thermal adaptation of vertebrates (acclimatization) to seasonal temperature changes or acclimation to experimentally induced temperature alterations) a general rule had been elaborated $(2,20,22-24)$, indicating "the lower the environmental temperature is, the higher is the degree of sialylation (= polarity) of brain gangliosides". This trend had been found to be partly due to alterations in the sensitivity of brain gangliosides of warm- verses cold adapted animals towards membrane-bound sialidases.

In summary the large diversities in concentration and composition of brain gangliosides during phylogenetic development and ecophysiological adaptation of the vertebrates speaks in favor of the assumption of a consequent and functional selection of these lipids parallel to that of a more efficient organization of the nervous system.

2.1.2. Ontogenetic aspects (for review comp. 25-33)

During ontogenetic development of vertebrates, dramatic changes in the formation of brain gangliosides occur, which can be correlated with the various stages of neuronal differentiation $(=$ neurogenesis). Gangliosides can serve as marker compounds for the level of neuronal differentiation insofar as the expression of individual ganglioside species is correlated with characteristic stages of nerve cell development (Fig. 5):

- The phase of proliferation of neuronal and precursor cells is characterized by a relative simple set of gangliosides, predominantly of $\mathrm{GD}_{3}$ (and $\mathrm{GD}_{2}$ ), and by the absence of more complex ganglioside species.

- The period of cell migration and differentiation is correlated with a drastic decrease in $\mathrm{GD}_{3}$ but a major biosynthesis of polar polysialogangliosides belonging predominantly to the c-pathway of biosynthesis $\left(G_{1 C}, G_{1 C}, G P_{1 C}, G^{\prime \prime} H^{\prime \prime}, G^{\prime \prime} S^{\prime \prime}, \quad\right.$ comp. Fig. 2).

- The phase of fiber growth and synapse formation, during which the total ganglioside biosynthesis is enhanced several-fold, is characterized by a sharp rise of $\mathrm{GD}_{1 \mathrm{a}}$ and $\mathrm{GT}_{1 \mathrm{~b}}$; simultaneously the expression of c-pathway polysialogangliosides decreases.

- The onset of myelination induces an increased accumulation of $\mathrm{GM}_{1}$ and $\mathrm{GM}_{4}$. This last developmental phase, 
組成や生合成の大きな変化とのあいだに有意 な関係があることが示されている（総説は10 -12を参照）。

神释細胞系に関しては、外から加えたガン グリオシドが細胞增殖を阻害するよりはむし ろ增強し、in vitroで神経細胞を增殖させた り分化させたりするばかりではなく、in ViVoで神経の維持や生存、修復を促進するよ うな軸索生成能や神経栄養素様の性質を持つ ことが見い出された(13)。しかしながら、後 者の研究にはまだ部分的に矛盾したものもあ るので、そしてまた特にこの研究分野は急激 に成長しており幾度か総説も書かれているの で(8,9,14)、この面からはここでは論じない ことにする。現在までのところ、内在性のガン グリオシドの細胞代謝における機能的な役割 に関するわれわれの知識はまだ満足できるす のではない。

特に神経系に焦点を当てて本論文では神経 系におけるガングリオシドの機能的役割に関 する最新の知見について要約してみたいと思 う。この点に関しては神経活動のほとんどす べての段階は、特に電気反応性は、細胞外の力 ルシゥム濃度の変化によって修飾され得るこ とを強調しなければならない。シナプス末端 の細胞内カルシゥムイオン濃度 ( $\mu \mathrm{M}$ ルベル) は細胞の代謝反応を開始させる第 2 番目のメ ッセンジャーとして働くことが見つけられた 一方で、細胞外カルシウムイオン濃度（mMレ ベル）は外部からの信号を内部にもたらすこ とができる第 1 番目のメッセンジャーとして 機能していると推測されている。それは、神 経の場合では、電気信号化された情報を前シ ナプス末端から後シナプス末端に内面化 (internalization)することを意味する。長期 適応の過程（たとえば、温度適応、再生、情 報の蓄積、15-20）に関する限りでは、シナブ ス膜の物理化学的な性状の変化は情報の短期 のシナプス伝達に関係していると考えられる。

こうした背景から、本総説では脳ガングリ オシドの主な生理学的、生物電気的、生化学 的、物理化学的特性の概観について言及した い。さらに、シナプス伝達と長期神経適応の
過程の調節因子として脳ガングリオシドが関 わっているという作業仮説に関しても論じた い(15-20参照)。

\section{2. 脸ガングリオシドの生理学的、生物電気 的、生化学的、物理化学的特性の概要}

ガングリオシド研究の活動の種々の分野に おける発表論文の数が压倒的に多いので、本 論文ではシナプス伝達と神経系内での情報の 蓄積におけるガングリオシドの役割を理解す るために特に意味がある論題にしぼって結果 を考察する。

\section{1. 脳ガンクリオシドの生理学的特性}

神経細胞におけるガングリオシドの生理学 的機能を理解するためには、これらスフィン ゴ糖脂質の動物界および遺伝的変異体を含む 個体発生における発現に関して詳細な知見を 得ることが重要であると考える。

2.1.1. 系統発生的及び生態生理学的見地 (総) 説は2,6,18,21-23を参照)

脳のガングリオシドの濃度と構成（たとえ ば、シアル酸付加の程度＝極性）は、神経の 組織化の系統発生的程度と脊椎動物の温度環 境に対する生態生理学的適応によって大きく 変化する。下等な変温動物（魚類、両生類、 爬虫類）では、その含有量は100ないし 800 $\mu \mathrm{g}$ シアル酸 $/ \mathrm{g}$ 新鲜脳重量であり、恒温動物

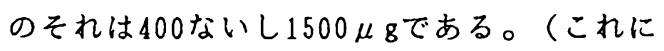
付随して神経系のシアロ糖蛋白質の含有量が 減少することが観察されている。）ひとつの 脳のなか（すなわち、前脳、中脳、脳幹、小 脳、脊涟）でガングリオシドの含有量を比較 すれば、全体としての傾问は、濃度は系統発生 的に新しい部位(前脳) から古い部位 (脊葡) に向かって降下しているといえる。

下等な変温脊椎動物における脳のガングリ オシドは、ラクトースー、ガングリオトリオー スー、ガングリオテトラオースーのコア構造を 基礎にした多種類の極性の構成成分から主と して構筑されている(Fig. 2)。このことに関 しては、南極海に棲む魚類 (ice fish)におい ては脳のガングリオシドは動物界では最も極 